4.

\title{
Congenitales, wahrscheinlich syphilitisches Myom des Herzens.
}

\author{
a. Krankheits- und Sectionsbericht. Briefliche Mittheilung \\ von Dr. Kantzow, \\ Director der Hebammenlehranstalt zu Magdeburg.
}

Ich äbersende Ibnen Herz nebst Lungen einer 8monatlichen todtgebornen Frucht, bei welcher die Epidermis in ihrer ganzen Ausdehnung gelöst and zum Theil in grossen Fetzen verloren gegangen war, so dass die rothbraune Cutis stellenweise blosslag. Der Fötus hatte nicht den Geruch todtfaul geborner Kinder, auch das Fruchtwasser war nicht ühelriechend, die Placenta ganz normal, die Nabelschnur dick, am fötalen Ende schwarzbraun.

Die Section ergab an den Unterleibseingeweiden, namentlich in Leber, Milz, Nieren keine pathologische Veränderung, wohl aber in der Brust. Beide Pleuraböhlen waren mit blutig gefürbter Flüssigkeit angefüllt, die Lungen ödematös ausgedehnt, so dass sie fast das Aussehen fötaler Lungen verloren hatten, auf Durchschnitten schwarzbraun, auf der Oberfläche stark gefüllte Venen, im Wasser untersinkend. Im Herzbeutel wenig blutiges Serum. An dem Herzen vorn in der Gegend, wo der Sulcus longitudinalis auf den circularis trifft, ein flacher Tumor, wohl von Entzündung des Herzfleisches, ungefähr $\frac{1}{2} Z_{0}$ oll in der Breite, etwas härter anzufühlen, als die übrige Herzsubstanz und unter dem Pericardialüberzuge, sowie auf dem Durchschnitte punktförmige weisse Exsudate zeigend. - Die Thymus normal. Die rechte Seite des Halses an der vorderen Hälfte geschwollen und daselbst unter der Haut, von dunkel blutig gefärbter Gallertmasse umgeben, eine mit kleinen weisslichen Ablagerungen durchsetzte Drüsenpartie.

Das Kind ist von einer jungen Frau geboren, welche nach der Geburt ihres ersten lebenden Kindes, vielleicht durch die Amme angesteckt, gleichzeitig mit dieser, dem Kinde und ihrem Manne sypbilitisch erkrankt und seit der Zeit 4mal von todten Früchten entbunden worden ist. Die Leute sind sehr sorgsam ärztlich behandelt worden, und da sich an denselben seit 5 Jahren keine Spuren von Syphilis wieder verrathen haben, die Frau ein blühendes Aeussere hat und diessmal in 4 bis 5 Wochen das normale Ende der Schwangerschaft erreicht hätte, so glaubte der Hausarzt der Familie die Syphilis ausgetilgt und kommt nun, da er den Bemühungen der Therapie und den Wünschen der Eheleute günstigere Ziele sichern möchte, in eine schwierige Lage.

Es entsteht die Frage, ob, abgesehen von den Erscheinungen an der Haut, die Befunde an Herz, Lungen und am Halse - wie ich es meine - mit einiger Sicherbeit auf congenitale Syphilis zu beziehen sind, da sie von dem Gewöhnlichen doch woh? abweichen.

Magdeburg, den 8. November 1865 . 